Хитра О. В., к.е.н., доцент Хмельницький університет управління та права імені Леоніда Юзькова м. Хмельницький, Україна

DOI: https://doi.org/10.30525/978-9934-26-028-5-30

\title{
РІВЕНЬ ЗАДОВОЛЕННЯ РЕКРЕАЦІЙНИХ ПОТРЕБ ЯК ПЕРЕДУМОВА РОЗВИТКУ ЛЮДСЬКОГО КАПІТАЛУ
}

Людський капітал - це форма організації, функціонування i розвитку продуктивних сил людини, інтегрована до системи соціально-інноваційної ринкової економіки як провідний чинник економічного зростання і єдиний ресурс, який має здатність оновлюватися та вдосконалюватися [1, с. 25]. 3 інвестиційної точки зору, це нематеріальний актив, який накопичується та примножується за рахунок інвестицій в освіту, охорону здоров'я, відпочинок.

Очевидною тенденцією сучасності $є$ скорочення фізичних зусиль людей удома й на робочому місці, що супроводжується зростанням розумових та нервово-психічних навантажень $[2$, c. 71$]$. У цих умовах рівень рекреаційних потреб працівників не просто зростає (ставлення до відпочинку трансформувалося від неусвідомленої до усвідомленої потреби), а більш диверсифікованими стають вимоги до структури рекреаційних послуг [3, с. 19].

Терміном «рекреація» (у перекладі 3 фр. «recreation» відпочинок, від лат. «recreatio» - відновлення сил) позначають відновлення чи відтворення фізичних і духовних сил, витрачених людиною у процесі життєдіяльності. Це система заходів, пов'язаних з використанням вільного часу людей для оздоровчої, культурно-ознайомчої і спортивної діяльності, яка спрямована на задоволення широкого кола особистісних і соціальних потреб [4, с. 522].

Неусвідомлення власних рекреаційних потреб, невміння правильно відпочивати веде до зростання захворювань, 
пов'язаних 3 порушенням природної рівноваги між витратами життєвих сил та їх відновленням. Відтак, необхідне створення спеціалізованих рекреаційних установ, в яких комплекс рекреаційних послуг відповідав би рекреаційним потребам [2, с. 72].

Слід зазначити, що формування рекреаційних потреб відбувається під впливом соціально-економічних, демографічних, особистісно-поведінкових, ресурсно-екологічних, політичних чинників, а також факторів культурного і суспільно-психологічного характеру [3, с. 19; 5, с. 26]. Різні культурні цінності, відмінна цивілізаційна ментальність народів, розмаїття національних характерів та уподобань, соціально-економічний рівень життя суттєво впливають на рекреаційні потреби, їх трансформацію у просторі й часі [2, с. 73].

Рекреаційні потреби задовольняються через низку рекреаційних занять: зміна звичного оточення, відновлення здоров'я, зняття втоми, пізнання навколишнього світу, задоволення естетичних потреб, духовне збагачення, втеча від повсякденності [5, с. 27]. Розрізняють індивідуальні, групові і суспільні рекреаційні потреби. Індивідуальні потреби - у відновленні фізичних i духовних сил людини, в іiі фізичному, інтелектуальному й духовному вдосконаленні; групові - це специфічні потреби певних соціальних груп населення; суспільні - у розширеному відтворенні соціально-трудового й соціальнокультурного потенціалу суспільства [3, с. 19]. На нашу думку, така типологія корелює 3 рівнями (особистісним, мікро- та макроекономічним) і складовими (біологічною та культурною) людського капіталу.

Рекреаційні потреби задовольняються у процесі добового, тижневого, сезонного та річного рекреаційних циклів, кожен 3 яких має власну ритміку і просторовий механізм саморегуляції. Так, для добової рекреації характерний обмежений і водночас досить стійкий набір рекреаційних занять (наприклад, ранкові пробіжки). Тижневим рекреаційним потребам властиве поєднання активних рекреаційних занять на природі 3 культурнопізнавальними або розважальними. Сезонні рекреаційні потреби 
є більш вмотивованими i пов'язані 3 порівняно тривалою рекреаційною діяльністю. Річні рекреаційні потреби задовольняються під час відпустки [6, с. 137].

На мікроекономічному рівні відтворення людського капіталу йдеться про готовність і фінансову спроможність роботодавців створити для працівників належні умови для рекреації; це, зокрема, може бути організація інтенсив-турів як сучасної форми заохочення.

На макроекономічному рівні слід проаналізувати динаміку інвестицій у суспільні інститути, які формують середовище відтворення людського капіталу шляхом задоволення актуальних рекреаційних потреб населення. Сукупність галузей і видів економічної діяльності, які забезпечують населення рекреаційними послугами і створюють передумови для рекреаційної діяльності, позначають терміном «рекреаційне господарство» [7, с. 5].

Рекреаційні потреби реалізуються шляхом здійснення рекреаційної діяльності, під якою розуміють один з комплексних видів життєдіяльності людини, спрямований на оздоровлення i задоволення духовних потреб у вільний від роботи час. Ця діяльність характеризується мінливістю, розмаїтістю, незвичністю поведінки людей, самоцінністю процесу [5, с. 27-28].

Згідно з діяльнісним підходом, виділяються такі основні види життєдіяльності людини: трудова, споживча, соціоприродна, відтворювальна, екістична. Специфіка рекреації у тому, що вона характеризує всі компоненти життєдіяльності. Зокрема, трудова життєдіяльність пов'язана 3 працею у сфері надання послуг 3 оздоровлення та відпочинку людей, споживча - зі споживанням різноманітних послуг, відтворювальна - 3 використанням вільного часу для відновлення сил людини, соціоприродна - 3 потребою спілкування людини 3 живою природою, розселенська (екістична) - з розміщенням рекреаційних об'єктів у різних типах поселень $[2$, с. 75; 7, с. 5-6]. Це, на наш погляд, підкреслює значимість інвестицій у рекреаційну діяльність в контексті забезпечення ефективного відтворення людського капіталу. 
Середовище, в якому здійснюється (може здійснюватися) рекреаційна діяльність, називається рекреаційним. До нього входять: природне середовище; квазіприродне (природне i антропогенне) - лісопарки, водосховища; культурне - історикокультурні об'єкти; техногенне - технічні розважальні комплекси, інфраструктура; соціальне середовище. Позитивними рисами рекреаційного середовища є високий рівень забезпеченості ресурсами для рекреації, сприятлива екологічна ситуація, розвинена сфера послуг, стабільна політична ситуація та ін. Негативними рисами є забруднення довкілля, низький рівень безпеки, низька транспортна освоєність території тощо [7, с. 13-14].

Поєднання компонентів природи, соціально-економічних умов i культурних цінностей, які виступають умовою задоволення рекреаційних потреб людини, позначають поняттям «рекреаційні ресурси». Це об'єкти, явища і процеси, які можуть бути використані для організації рекреаційних занять; вони характеризуються оригінальністю, естетичною привабливістю, цілющооздоровчою значимістю $[5$, с. 59; 8, с. 36]. Соціальна функція рекреаційних ресурсів полягає у тому, що вони забезпечують відновлення та розвиток життєвих сил, витрачених у процесі трудової діяльності, тобто слугують для регенерації здоров'я i підтримки працездатності [4, с. 523].

Відповідно, рекреаційний потенціал виражається кількістю очікуваного рекреаційного ефекту, або спроможністю рекреаційних ресурсів до відновлення і витримування певних рекреаційних навантажень з урахуванням екологічних критеріїв [4, с. 524].

Досягнутий рівень господарського потенціалу рекреації у процесі територіального поділу праці позначається терміном «рекреаційна освоєність території» [5, с. 24]. Цей показник характеризується насиченістю території елементами рекреаційної інфраструктури, рекреаційним навантаженням, ступенем розвитку рекреаційного господарства. Здатність певної території забезпечувати здійснення комфортної рекреаційної діяльності без деградації природного та історико-культурного середовища позначають поняттям «рекреаційна місткість». Також є доціль- 
ним здійснення моніторингу рекреаційного навантаження, що означає рівень сукупного антропогенного впливу на природний комплекс у процесі рекреаційної діяльності [3, с. 14].

Таким чином, вагомою передумовою розвитку людського капіталу доречно вважати рівень ідентифікації та задоволення рекреаційних потреб як окремих індивідів, так і професійнокваліфікаційних соціальних груп, трудових колективів підприємств і населення країни в цілому. У свою чергу, для цього має бути належним чином організована рекреаційна діяльність, матеріальним базисом якої $є$ рекреаційне господарство. У ході рекреаційної діяльності активно використовуються природні, історико-культурні та соціально-економічні ресурси, поєднання яких утворює складну систему, що потребує виваженого управління на державному рівні. При цьому досить важливо підвищувати рівень рекреаційної освоєності території, не забуваючи, водночас, про те, що надмірне рекреаційне навантаження може призвести до погіршення стану екологічного середовища й, відповідно, обернутися втратою вітального капіталу суспільства.

\section{Література:}

1. Артеменко Л. Б. Людський капітал: наукові підходи та стан формування в Україні. Галиџький економічний вісник. 2016. Т. 50. № 1. С. 22-31.

2. Терещенко В.І., Ш Шанько Л.О., Ч Чаплигін В.П. Соціально-економічні основи рекреації та туризму: навчальний посібник. Київ : Міленіум, 2019. 154 с.

3. Чир Н.В. Рекреаційна географія: навчально-методичний посібник. Мукачево : вид-во Дишкант С.Я., 2019. 156 с.

4. Муска К.К. Теоретичні підходи до розуміння сутності дефініцій «рекреаційні ресурси» та «рекреаційний потенціал». Глобальні та національні проблеми економіки: електронне наукове фахове видання. 2018. Вип. 21. C. 521-526. URL: http://global-national.in.ua/archive/21-2018/99.pdf (дата звернення: 20.01.2021).

5. Поколодна М.М. Рекреаційна географія: навчальний посібник. Харків : ХНАМГ, 2012. 275 c. URL: https://tourlib.net/books_ukr/pokolodna-rg.pdf (дата звернення: 19.01.2021).

6. Любіцева О.О., Кочеткова І.В. Теоретичні та прикладні питання рекреаційно-туристичного природокористування в столичному місті. Культура народов Причерноморья. 2009. № 176. С. 136-138. 
7. Пушкар Б.Т., Пушкар 3.М. Територіальна організація рекреаційного господарства регіону : монографія. Тернопіль : Вектор, 2014. 196 с.

8. Гурова Д.Д, Фролов М.О., Журавльова С.М., Кукліна Т.С., Сердюк О.М. Рекреаційна географія : навчальний посібник. Запоріжжя : ЛІПС, 2010. 103 с. 